\title{
Interface restrictions on verb second
}

\author{
André Meinunger
}

ZAS Berlin

\section{Introduction}

Verb second (henceforth V2) in Germanic goes on being a mystery. It has been a focus of research for decades and still enjoys a lively and controversial debate. The fact that the German finite verb appears in the sentence final position ('rechte Satzklammer', right sentence bracket) in subordinate clauses and in the second position in main clauses ('linke Satzklammer', left s.b.) has all possible analyses: the canonical one is still standard and goes back to den Besten's analysis of Dutch (1977/1983). According to it the finite verb raises via head-tohead movement from its base position under $\mathrm{V}^{\circ}$ to the head-initial $\mathrm{C}^{\circ}$ node. Recently three different proposals are on the market: (i) Fanselow (2002, this volume) revives Holmberg's 'Münchhausen' idea, (ii) Müller (2002) proposes an analysis that does without head movement at all (see also Koopman and Szablolcsi (2000)), and Chomsky (2001) banishes verb second into the phonological component getting it outside the core area of syntax. A good overview can also be drawn from the volume 'Dimensions of movement' where all current sorts of movement approaches are presented (Alexiadou et al. 2002).

This article does not aim at defending the traditional approach or one of the new proposals, nor will it deliver yet another one. The intention of the present

\section{Linguistics in Potsdam 22 (2004): 51-81 \\ Ralf Vogel (ed.): \\ Three papers on German verb movement}


work is to point at two relatively unrelated observations, the correct analysis of which might help to decide for the correct approach.

What will become clear is that the V2 rule is not blind with respect to the interfaces. It is not a merely syntactic movement rule whose output is (to be) interpreted by the phonological component on the one hand and by the conceptual interpretative system on the other. It is rather such that both systems restrict V2, they have a direct influence on the verb getting to its position. We will see that parsing strategies guide V2: phonological processing as well as interpretation related parsing.

The paper is organized as follows. In the first part a special construction is presented and discussed. This relatively neglected pattern is given an analysis that recurs to phonological wellformedness constraints. It is shown that a tree gets a syntactic and a phonological interpretation, sometimes parallel and corresponding to each other - sometimes diverging. If either one fails to meet wellformedness conditions the derivation crashes. The second part discusses the behavior of speech act adverbials. These may appear in a position before a canonical CP, verb third emerges (V3). Often the same adverbials, however, are also fine in the canonical 'Vorfeld' (prefield) giving rise to a regular V2 structure. Sometimes V2 is not permitted. The reason for this pattern is a parsing effect that has a similar impact as other better known garden path effects. Both constructions thus show that $\mathrm{V} 2$ is restricted from outside the core syntax.

\section{Elements that block verb raising - a discussion}

\subsection{Haider's observation}

The crucial observation that led to the present investigation, which I will discuss in the first part, was made in Haider (1997). The following story is very much a 
recapitulation of Meinunger (2001). Haider considered the comparison constructions in (1) - (3) (slightly modified for our purposes). (1) consists of a periphrastic tense construal where the finite verb is an auxiliary that has moved to the V2 position. (2) is the unfelicitous attempt to move the full main verb of a simple tense into the V2 position.

(1) Der Wert hat sich weit mehr als verdreifacht. the value has self far more than tripled 'the value has far more than (only) tripled'

(2) *Der Wert verdreifachte sich weit mehr als.

(3) weil sich der Wert mehr als verdreifachte because 'self' the value more then tripled

Haider's argumentation goes as follows. The comparative element mehr (the German counterpart of more) must c-command its associate at s-structure. Since in the case at hand mehr quantifies over the verb verdreifach(en), the verb must stay in its base position inside the VP. This is not given in (2). A subordinate structure, where any verbal form occurs rightperipherally, i.e. not only in periphrastic tenses, renders the sentence grammatical because the verb does not raise over $\underline{\text { mehr }}(3)$ - at least in a stucture without a head final $I^{\circ}$, which Haider assumes.

Haider's explanation, however, is not completely compelling for several reasons: (i) under other circumstances verb movement does not care about scopal configurations depending on (so-called) d- or s-structure; (ii) other comparative constructions involving mehr allow the associate to appear to the left of it, and (iii) the same phenomenon of impossible verb movement can be observed in many other cases that do not involve comparison. 
Ad (i): Haider himself agrees that negative polarity verbs (NPIs) do not obey an s-structure requirement on the licensor c-commanding the polarity verb. The well-known case is brauchen, (something like need or must under negation and question operators) which can appear in the V2 position leaving its licensor (nicht in (4)) behind.

(4) Man braucht $t_{i}$ es *(nicht) zu sehen $e_{\text {i. }}$

one need it (not) to see _

'one need not see it'

It would be a mystery if the 'mehr als' comparative construction required s-structure c-command whereas negative polarity did not. This is even more surprising for NPI licensing is known to be a very strong s-structure phenomenon. Comparative constructions on the other hand are less strict (ad (ii)). In certain examples the comparative associate may precede mehr:

$$
\begin{aligned}
& \text { *Als Jo / okim Vergleich zu Jo / okverglichen mit Jo } \\
& \text { *than Jo / in comparison with Jo / compared to Jo } \\
& \text { hat Eva mehr Aufgaben gelöst. } \\
& \text { has Eva more tasks solved }
\end{aligned}
$$

'Compared to Jo, Eva solved more problems.'

The interesting thing, however, is that verb movement of the sort discussed here can be observed in more environments that are not related to comparison at all (iii). Thus, it seems that there is no blind mechanism that raises the finite verb in main clauses to $\mathrm{C}^{\circ}$ automatically and irrespectively of all factors. 


\subsection{The other constructions}

In the following paragraph I list a number of constructions (hopefully almost exhaustive) that behave very much like mehr als above, that is, they contain verbal forms in which the main verb must be placed after a certain element in the middle-field. In these cases V2-movement of the full verb form into $\mathrm{C}^{\circ}$ is ungrammatical. Some constructions below belong to informal spoken registers. The contrast, however, is very sharp:

(6) a. Der Angeklagte hat so gut wie gestanden. ${ }^{1}$ the accused has so gut wie confessed

b. weil der Angeklagte so gut wie gestanden hat / gestand

c. *Der Angeklagte gestand so gut wie.

'The accused almost confessed (his crime).'

(7) a. Der Wert hat sich nun soviel wie verdoppelt. the value has self now soviel wie doubled

b. weil sich der Wert nun soviel wie verdoppelt hat / verdoppelte

c. *Der Wert verdopplete sich nun soviel wie. 'In the meantime the value almost tripled.'

(8) a. Der Wert hat sich mehr denn verdoppelt. the value has self mehr denn doubled

b. weil sich der Wert mehr denn verdoppelt hat / verdoppelte

1 In order to prevent redundancy I outline the patterns displayed in examples (6) - (13). The a. example with perfect tense in main clause shape is glossed. The b. example in each block is not. It has subordinate shape with perfect and simple past tense separated by ' $/$ '. The c. example, which is always ungrammatical, is an attempt to raise the simple past tense verb to the V2 position. A tentative translation follows. Since in German simple past and perfect tense can be used synonymously, one translation is sufficient. 
c. *Der Wert verdopplete sich mehr denn.

'The value more than merely doubled.'

(9) a. Der Besuch hat sowas von geprahlt.

the guest has sowas von boasted

b. weil der Besuch sowas von geprahlt hat / prahlte

c. *Der Besuch prahlte sowas von.

'The guests were boasting in such an incredible manner.'

(10) a. Der Hamster hat so eine Art von gehustet.

the hamster has so eine Art von coughed

b. weil der Hamster so eine Art von gehustet hat / hustete

c. *Der Hamster hustete so eine Art von.

'The hamster sort of coughed.'

(11) a. Die Kommission hat nichts als gemeckert.

the commission has nichts als grumbled

b. weil die Kommission nichts als gemeckert hat / meckerte

c. *Die Kommission meckerte nichts als.

'The commission didn't do anything but grumble.'

(12) a. Die Kommission hat nichts außer gemeckert.

the commission has nichts außer grumbled

b. weil die Kommission nichts außer gemeckert hat / meckerte

c. *Die Kommission meckerte nichts außer.

'The commission didn't do anything but grumble.'

(13) a. Die Kommission hat weder gemeckert, ...noch... ${ }^{2}$ the commission has neither grumbled $\quad$...nor...

b. weil die Kommission weder gemeckert hat / meckerte, ...noch...

c. *Die Kommission meckerte weder, $\quad$...noch...

2 This example is a bit different and less clear. weder can induce V2 (13 d.) and save the construction. 
d. weder meckerte die Kommission, ...noch...

'The commission neither grumbled, nor...'

All examples become grammatical if something follows the underlined chunks. In some cases it even suffices to have a separable prefix of a morphological complex verb (17):

(14) Der Angeklagte gestand so gut wie gar nicht.

(15) Der Besuch prahlte sowas von \{oft / unverschämt / peinlich...\}.

(16) Die Kommission meckerte weder davor, (noch danach).

(17) Unser Besuch gibt sowas von an.

A similar pattern of verb movement blocking can be observed in other languages. French has a construction consisting of a negative clitic element which in most cases is morphologically attached to a finite verb in $\mathrm{I}^{\circ}$ and semantically associated with a constituent that starts with the element que. Such a construction triggers a focus reading on the relevant phrases - similar to only in English. In perephrastic tenses and constructions movement of the full verb across que triggers ungrammaticality (19). Putting something after que makes the sentence grammatical (20) again. In case the verb is supposed to be the target of focus in a non-periphrastic construction, a dummy verb (faire ? do-support) has to be inserted (21).

(18) Il n'a que bossé.

(French)

he not-has 'que' hard-worked

'He didn't do anything but work.'

(19) *Il ne bosse que.

he not hard-work that 
'He doesn't do anything but work.'

(20) Il ne bosse que le dernier jour avant l'examen / pour son frère... he not hard-work 'que' the last day befor the exam / for his brother 'He works hard only the day before his exam / only for his brother.'

(21) Il ne fait que bosser. he not does 'que' work-hard 'He doesn't anything but work.'

Similar constructions also occur in English. The situation is different insofar as that there is no verb movement of full verbs. However, some quantifying elements that target the verb must precede it, whereas others may also follow the verb.

(22) He somehow wheezed

(23) He sort of wheezed.

(24) He wheezed somehow.

(25) *He wheezed sort of. (under unmarked flat intonation)

Here one can also add examples inspired by Kajita, who discovered the peculiarities of such constructions as early as 1977. He is, however, not concerned with the contrast of the examples in (26) to (29).

(26) ?This amount far from suffices.

(27) *This amount suffices far from.

(28) The number of visitors to London close to tripled.

(29) *The number of visitors to London tripled close to. 


\subsection{A possible explanation}

A look at the elements that may block verb movement suggests two possible directions for an explanation: one is rather semantic, the other one is lexical/phonological. In the end neither will be completely satisfying in isolation and a mixed approach will be correct. It will be argued, however, that the latter one is much more important. Let us start with the first option. All the underlined elements in examples (1) - (29) somehow indeed operate on the verb, i.e. they focus it, measure or compare it. The explanation might thus be something along Haider's lines: the operator must c-command the operandum at s-structure. To put it differently, the quantifying element seems to have to c-command and therefore linearly precede the verb. A similar idea has been proposed in the 'fast'-generalization for German advocated by Rapp and von Stechow (1999). fast roughly means almost and as such it is close in meaning to other expressions blocking V2, e.g. soviel wie, so gut wie (see above). Rapp and von Stechow give the judgements in (31), (32) and claim:

(30) 'fast-generalization: fast cannot attach to a phrase with a phonetically empty head.

(31) Gestern hätte sie mich fast getroffen.

yesterday had she me almost met.

'Yesterday she almost met me.'

(32) *Gestern traf sie mich fast.'

'fast' is also an element which operates on the verbal meaning. However, a rule like (30) would be too strong. There are many other constructions in which the operator element need not c-command the verb. That means although the verbal action is quantified over, the full verb may raise over its operator and leave the 
latter behind. Also fast - contrary to what Rapp and v. Stechow claim - can certainly be stranded by the verb (even (32) is grammatical for most speakers).

(33) Genug! Der Reifen platzt fast.

enough! the tire bursts almost

'Enough! The tire is likely to burst soon.'

(34) Sie erkannte mich fast.

she recognized me fast (=almost)

'She almost recognized me.'

The same is true for operator words like nicht, nur, wieder, kaum, mehrmals and so on. Each of them can be used to quantify over the verbal action and yet is completely compatible with a finite verb to their left and moreover, all of these expressions can stand right-peripherally, i.e. they do not require a continuation. Almost all of these elements are semantically very similar, or even synonymous to some of the blocking elements. For example strandable nur is synonymous to nichts als, which does not allow for stranding (see above (11)):

(35) Der Wert verdoppelte sich fast_. / wieder_. / kaum_. / nicht_. / nur_. the value doubled self almost / again / hardly / not / only

Given this, the facts seem to call for another option, possibly the one with a phonological background. It appears that all the blocking elements - even across languages - and irrespective of the verb's final landing site (no or very little verb movement in English, $\mathrm{I}^{\circ}$ in French and $\mathrm{C}^{\circ}$ in German) end in or even only consist of an element that $\mathrm{CAN}$ be analyzed as either a $\mathrm{C}^{\circ}$ element, or as some sort of functional preposition $\left(\mathrm{P}^{\circ}, \mathrm{K}^{\circ}\right)$. 
I would like to go here through all elements mentioned so far that are able to block verb movement. First there wie from so gut wie, and soviel wie. Apart from its status as an interrogative or relative manner pronoun, 'wie' can act as a C $^{\circ}$ (Zimmermann 1991, also Hahnemann 1999 see below). It does so with a special semantics in subordinate clauses selected by verbs of perception as in (36). In contrast to the canonical complementizer dass (=that), the use of wie implies that the matrix subject was a witness of the hair cutting process, a reading which is not obligatorily triggered by the use of dass, hence the English translation with the acc-ing construction.

(36) Ich habe gesehen, wie du ihm die Haare geschnitten hast.

I have seen, 'wie' you him the hair cut have

'I saw you cutting his hair.'

wie also appears in comparative constructions of equality. Its corresponding element of inequality in Standard German (not necessarily in substandard dialects) is als. als is another element able to block verb movement, see above. I suggest that it is possible to analyze many of its uses as instances of $\mathrm{C}^{\circ}$ as well (also proposed in Hahnemann 1999). Of course there are problems with such an analysis:

(37) Er tut so, als wüsste er alles _.

vs. *Er tut so, als _ er alles wüsste he does so, as knew he everything

(38) Er tut so, als ob er alles wüsste.

(39) Er tut so, als wenn er alles wüsste. 'He pretends to knew everything.' 
(37) shows that als cannot block V2 in subordinate sentences, which makes it unlikely to act as a regular $\mathrm{C}^{\circ}$. (38) and (39) show that only if CP-recursion is admitted, could als possibly be a $\mathrm{C}^{\circ}$. In a different analysis it must be something else because $\underline{\mathrm{ob}}(=\mathrm{if})$ is the relevant $\mathrm{C}^{\circ}$. In one construction, however, $\underline{\text { als seems }}$ to act a relative complementizer to the modal adjunct insofern (or insoweit). Here most speakers can use it in complementary distribution with dass.

(40) Das ist insofern günstig, als ich dann noch in Berlin sein werde.

This is insofar opportune 'als' I then still in Berlin be will 'This is opportune insofar as that at that time I will still be in Berlin.'

(41) (?) Das ist insofern günstig, dass ich dann noch in Berlin sein werde.

In southern varieties, however, doubling emerges again and (42) seems to be structurally close to (38) and (39).

(42) Das ist insofern günstig, als dass ich dann noch in München sein werde.

A similar point can be made with respect to $\underline{\mathrm{außer}}^{3}$, which is the next element making verb movement crash. außer behaves almost exactly as als, only that instead of ob it combines with wenn (as in (44) or falls, which both translate into English with $\underline{\text { ff, }}$ or marginally again with $\underline{\text { dass: }}$

(43) Er tut es, außer du tötest den Hund. he does it except you kill the dog vs. *Er tut es, außer du den Hund tötest

(44) Er tut es, außer wenn du den Hund tötest

3 Note that there is a crucial difference, however. außer cannot trigger V2, itself 'representing' the 'Vorfeld', whereas als can ((40) vs. (43)). 
(45) Er tut es, außer falls du den Hund tötest

'He'll do it, unless you kill the dog.'

(46) ?Er tut es, außer dass du den Hund tötest

The solution to this 'problem' is not far fetched: all these constructions call for an analysis in terms of either CP-recursion or the assumption of a split CP layer: als can then be considered a head element in a split left periphery (Rizzi 1997). At any rate the claim made here - contrary to Haider - that it is the als, and not the mehr that triggers the failure of verb movement in (2). denn - the next element to be considered - is just a synonym of als in comparative constructions. It means the same, sounding just a bit old-fashioned. In other contexts denn behaves as another sort of $\mathrm{C}^{\circ}$ that blocks $\mathrm{V}$-to-C, but obligatorily embeds a V2 structure. In yet other constructions it seems to be an ellipsis of es sei denn (= unless), in which case it is synonymous with außer

(47) Er tut nichts (es sei) denn faulenzen. he does nothing (it be) 'denn' faulenzen

(48) Er tut nichts außer faulenzen.

'He doesen't do anything but laze around.'

The final blocker in German is von, which cannot be analyzed as a $\mathrm{C}^{\circ}$. von, like English 'of', is a semantically empty preposition, thus a $\mathrm{P}^{\circ}$, or $\mathrm{K}^{\circ}$. So are 'to' and arguably 'from'. French que is unproblematic. It is the complementizer par

4 In other positions different from the middle-field es sei cannot be left out. The parallelism with außer remains, however:

(i) Er tut es, es sei denn du tötest den Hamster_. $\quad$ vs.

*Er tut es, es sei denn du den Hamster tötest

(ii) Er tut es, es sei denn falls du den Hamster tötest

(iii) Er tut es, es sei denn wenn du den Hamster tötest 
excellence. Another regular French complementizer is si (if, whether). Here the data are less clear, the facts seem to be similar, however ${ }^{5}$. There is definitely a contrast.

(49) (?)Il n'a pas si bossé que ça.

He neg-has not si hard-worked que this

Something like 'He didn't work THAT hard...'

(50) *Il ne bosse pas si que ça.

(51) ?Il n'a pas si bossé qu'il soit fatigué.

He neg-has not si hard-worked que'he is-subj tired

'He didn't work so hard that he should be tired.'

(52) *Il ne bossait pas si qu'il soit fatigué.

weder is a more complicated case. Its categorization as a $\mathrm{C}^{\circ}$-element is not evident. However, it does not seem impossible to analyze it as such. In any case

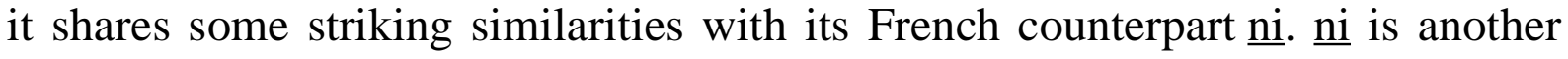
element which - similar to que - associates with clitic negation. Periphrastic tense constructions are acceptable (53). Ordinary verb movement in simple tenses is impossible (54). Auxiliaryless constructions must resort to other strategies. Either like in German, where weder must be placed into Spec;CP or some related left peripheral position to precede the verb (55), 'ni' can be fronted and replace the negation clitic ne and hence precede the finite full verb (56), or again pleonastic 'faire' (do-support) can save the construction (57). So it seems

5 The structure here is more complicated for a constituent beginning with que is necessary. The relevant que-phrase (an NP or DP in (46) or a CP in (48)), however, opens a new phonological constituent and should therefore be considered as not being there, i.e. not

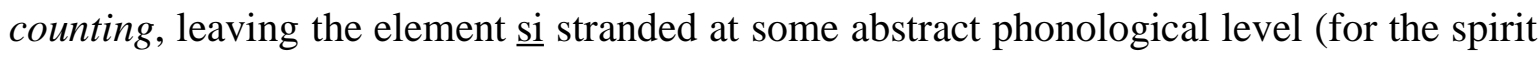
of this reasoning see below). 
that 'ni' (like weder) is very flexible in position and categorial status, what matters is its location in front of something.

(53) Il n'a ni travaillé, ni dormi.

he neg-has nor worked, nor slept.

(54) *Il ne travaille ni, (il ne) dort ni.

(55) Ni il travaille, ni il dort.

or

(56) Il ne travaille pas, ni ne dort.

(57) Il ne fait ni travailler, ni dormir.

(do support)

'He neither works, nor sleeps.'

None of the other quantifying elements that do NOT trigger ungrammaticality in case they stand right peripherally (e.g. nicht, nur, fast an so on, see (35) above) can be analyzed as either a complementizer or an empty preposition.

It thus seems that the impossibility of verb raising in the constructions considered here is due to the nature of the (last) elements that occur between the relevant verb positions, immediately before the right sentence bracket. I have argued that the blocking elements are canonical occupants of either $\mathrm{C}^{\circ}$ or $\mathrm{P}^{\circ}$ $\left(\mathrm{K}^{\circ}\right)$. A proposal that suggests itself is the following. According to Grimshaw's theory of extended projections (1991), these elements, i.e. $\mathrm{C}^{\circ} \mathrm{s}$ and $\mathrm{P}^{\circ} \mathrm{s}$ have something in common. They both close off the projection, i.e. they are the highest functional elements: $\mathrm{C}^{\circ}$ of sentences, $\mathrm{P}^{\circ}\left(\mathrm{K}^{\circ}\right)$ of noun phrases. Having this status implies being a functional category, i.e. the relevant elements act as function(al) words in their canonical use. Many authors have argued that function words are special and distinct from lexical words in that they are not phonological words whereas lexical words are. According to Hall (1999) such a view is widely accepted by phonologists. Being not a phonological word means that the relevant chunk of phonological material has to undergo phonological 
processes in order to survive at PF. Such processes can be attachment to a phonological word (cliticization) or stressing/focussing for example'.

The decisive factor in the case at hand seems to be a special variant of cliticization. Given the phonological deficiency of $\mathrm{C}^{\circ} / \mathrm{P}^{\circ}$-categories and the $\mathrm{C}^{\circ} /$ $\mathrm{P}^{\circ}$-analysis from above, the expectation is the following. The relevant functional elements can survive only if they can attach to a host to be a part of a phonological word. The host necessarily finds itself within the same phonological constituent. The most reasonable assumption is to let the beginning of a sentence, i.e. a CP in syntactic terms, coincide with the beginning of a phonological constituent that is or contains a phonological word. This phonological entity will then automatically serve as the host material for the phonologically deficient $\mathrm{C}^{\circ}$-element. The phenomenon is not different with extended nominal projections. This explains the proclitic-like behavior of the elements under discussion. Orphanage thus leads to un-grammaticality. Putting phonological material after the clitic-like element saves the structure (14)-(17), (20) (even though with semantic consequences). In case quantifying over the verb is intended, only some form of do-support (or its language specific counterparts) can achieve the desired result.

The peculiarity of the whole phenomenon is that in contrast to canonical cliticization the clitics discussed here need NOT move in syntax, but they get hold of a host 'with less effort'. They need not look for an attachment site, they just require something to follow them. If this requirement is not met, the structure is ungrammatical.

6 I am aware that some of the crucial items ('wie', 'von' etc.) can appear in isolation as independent elements (minimal words), however, not in the discussed examples where they are parts of larger expressions, which makes them very hybrid in character. Here they must integrate twice. Being a part of a larger unit makes it impossible for them to achieve the status of a phonologically (and morphologically) independent expression. 


\subsection{Riemsdijk's grafting approach as a possible alternative?}

Another promising way of coping with the data is to apply Riemsdijk's very appealing theory of grafting $(1998,2000)$. Riemsdijk in his work is concerned with true or apparent mismatches between syntax proper and other linguistic components (morpho-phonology, pragmatics). His theory seems to work well for a number of grammatical phenomena like transparent free relatives. Look at his analysis of (58).

(58)
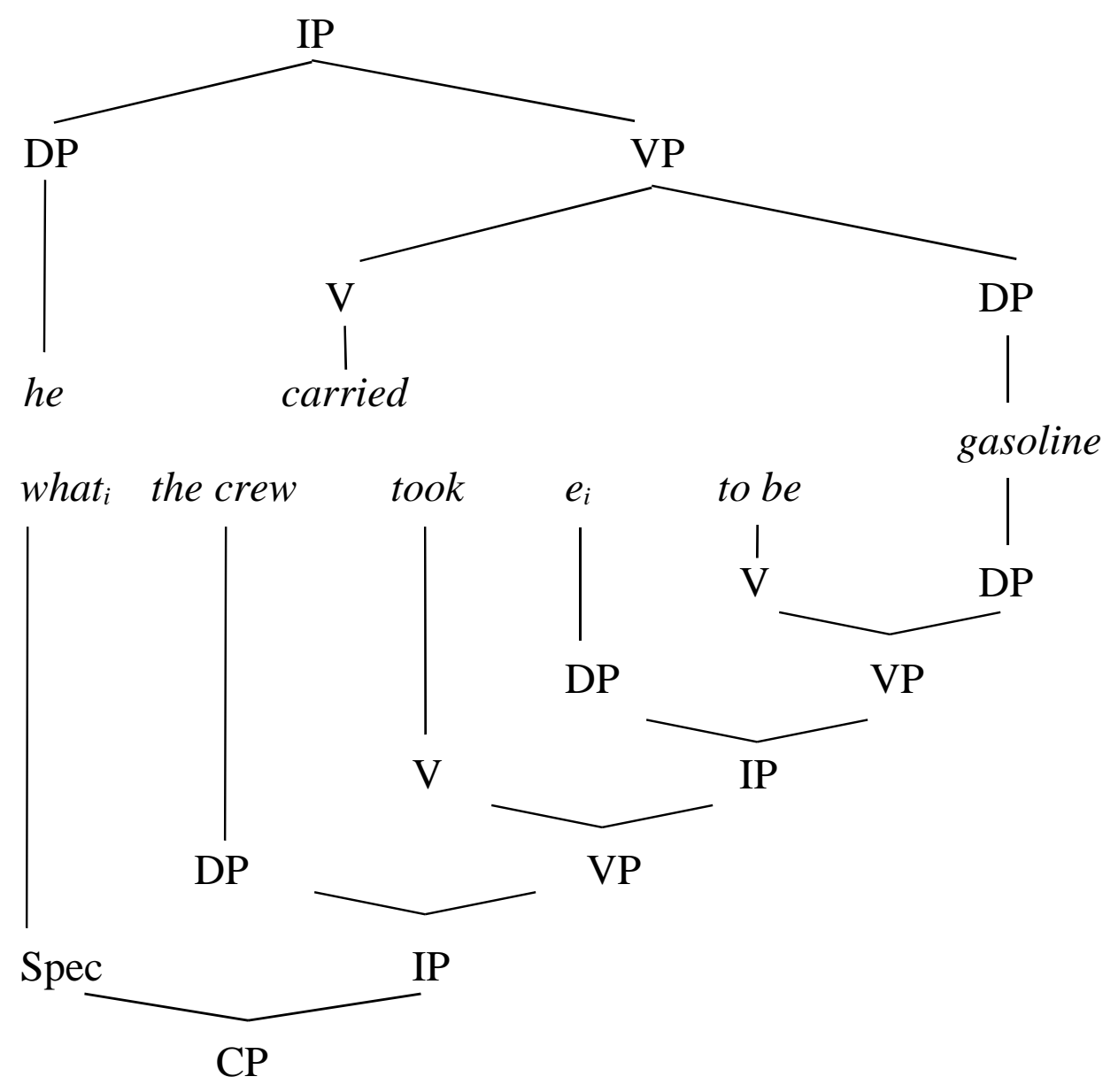

The same structure he proposes for cases like 'a far from simple matter' (59) first brought up in Kajita (1977 see above). 
Riemsdijk's analysis:

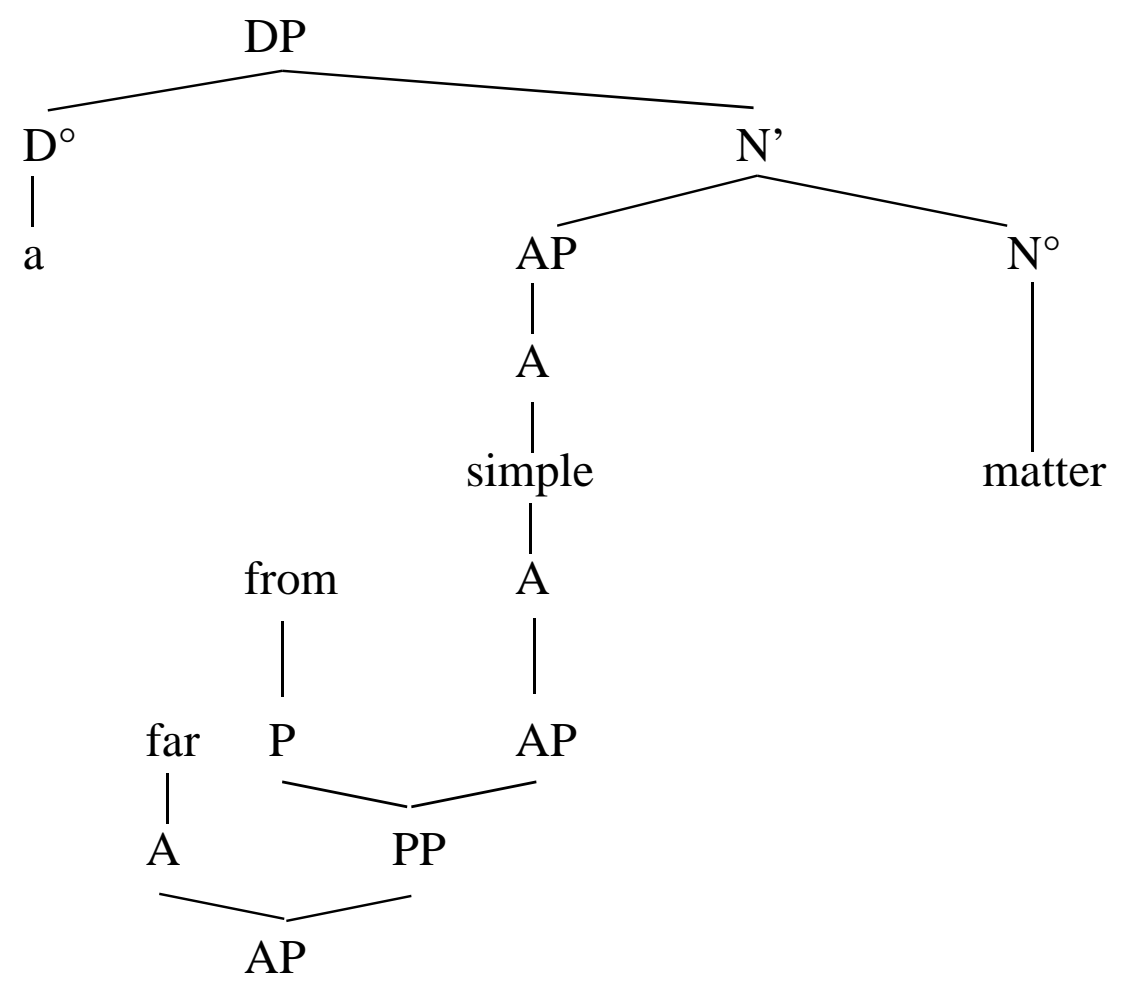

There seems to me to be an important difference between the two constructions, however. In (58) both trees can be generated independently and can potentially appear in different environments. The deepmost constituent 'gasoline' is a good argument of both verbs involved. This is not so with the adjective 'simple'. From a compositional, semantically driven point of view the bottom tree in (59) makes not much sense. From the labeling it does not fall out that 'simple' is the head of the construction. Instead it triggers a reading where 'simple' is the complement of the preposition 'from', which is not very uncontroversial'. On the contrary, the fact that almost any category can appear after $\mathrm{P}$ in such a construction makes it unlikely that $\mathrm{P}$ acts here as a regular preposition, all the more that an otherwise canonical DP complement seems to be the most marked option.

7 The given argumentation still holds if 'far' is to be interpreted as the grafted construction's head with 'from' only having the status of an empty $\mathrm{P}^{\circ}$ introducing the argument of the higher adjective. 
(60) She is far from out of the woods

PP

(61) This amount far from suffices

$\mathrm{VP}\left(\right.$ or even $\mathrm{V}^{\circ}$ )

(62) She is far from being an ideal partner/

IP or possibly VP or CP a beauty

(63) This is far from what I expected

$\mathrm{CP}$

(64) She solved the problem far from elegantly

AdvP

(65) $? ? *$ She is far from a beauty

DP

(66) $? ? / *$ She is far from an ideal partner

DP

(67) better: She is a far from ideal partner

AP like:

(68) a far from simple matter

AP

This suggests that there is no selectional restriction along the path in the Riemsdijk's bottom tree, but that 'far from' is to be analyzed as a quantificational adjunct, semantically and syntactically parallel to 'hardly'. This is already done in Kajita (1977 p. 50), who proposes a reanalysis.

Note also that Riemsdijk discusses transparent free relatives like (69) and (70).

(69) (?) John is what I'd call snoring.

(70) *John what I'd call snores.

Here Riemsdijk argues convincingly for string identity as decisive criterion for grafting, categorial affiliation being of minor importance. (69) is good because 'snoring' can have (i) a verbal and (ii) a nominal reading (as predicative NP, see Riemsdijk (1998) and Wilder (1998). (70) is out because 'snores' is unambiguously verbal and as such not licit in a (sub-) structure '*I'd call (that) snores.' So far Riemsdijk's argumentation is reasonable and seems to speak in favor of his grafting approach to transparent free relatives. But it reveals itself as problematic for the cases discussed here, for verbal forms CAN appear adjacent 
to elements like 'close to', 'far from' etc, see Kajita's example (71) and those given above.

(71) It far from exhausts the relevant considerations.

(72) it

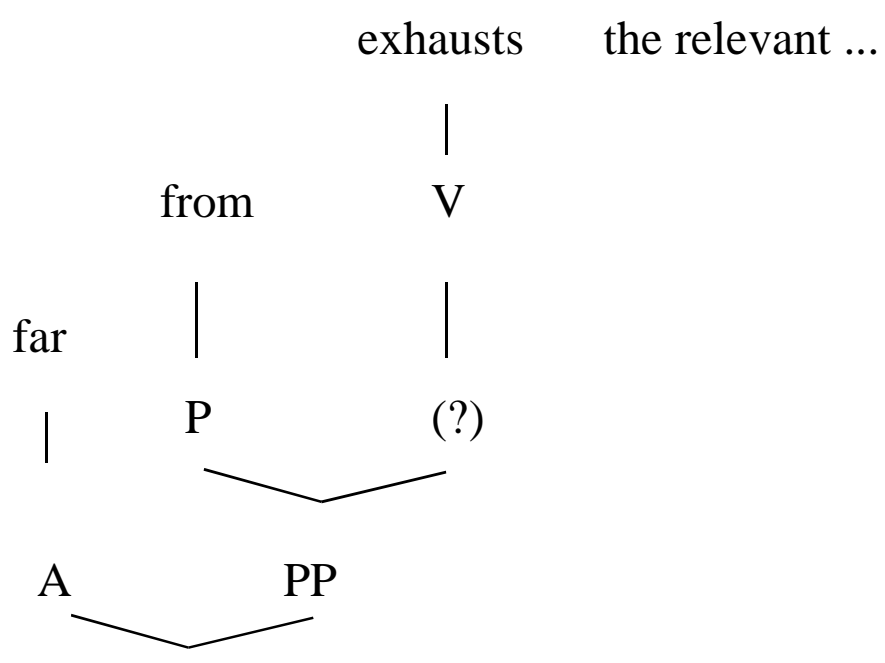

AP

The same applies to all the German examples given at the beginning of the article, which are the main subject of this investigation. It seems odd to argue for a tree like (72), where a finite verb(al element) is the ultimate argument of a preposition. Such an approach is even less convincing under an analysis where the German finite verb in subordinate clauses is argued to occupy a head final $\mathrm{I}^{\circ}$ node.

Instead the proposal advocated here is different, but in some sense similar. The idea is that there are indeed two distinct trees, but one is syntactic, the other one is phonological - a situation which is always given. 


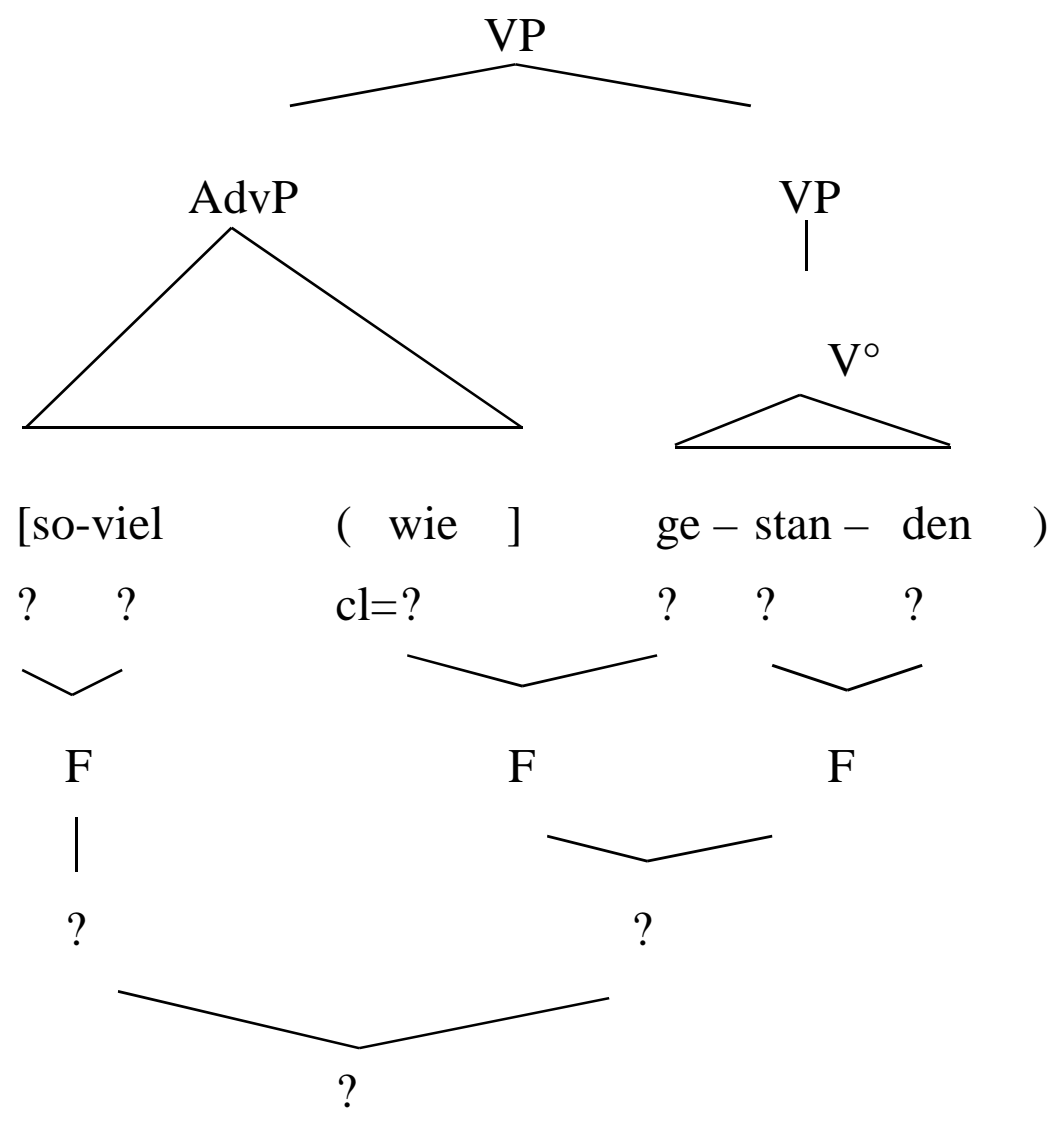

[ ] = lexical, semantic word boundary

(...) $=$ phonological (word) boundary

Nothing is strange with the analysis in (73). The upper part is classical syntax, the lower tree is classical phonology. Often there is a correspondence between syntactic and phonological trees, but it is well known that in some cases things pattern differently and the parallelism breaks down. It seems to me that in certain cases a morpho-syntactic: phonological mismatch is even systematic and motivated. Very often in derivational morphology (often considered to be a part of generative syntax) morpheme and syllable boundaries diverge systematically (in the case of suffixation). 
(74) find-2nd/sg

[(fin) (d][est )]

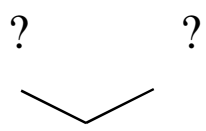

?

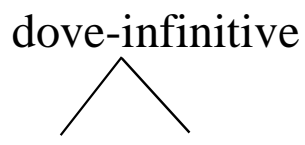

$[($ gra $)(b][$ en) $]$

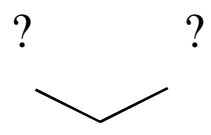

?

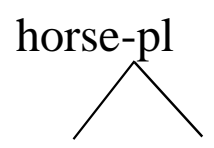

$[($ Pfer $)(d][e)]$

?

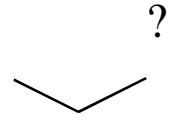

? forest-genitive

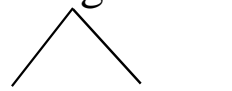

[(Wal)(d][es)]

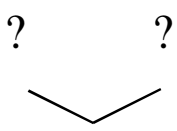

?

[ $]$ = morpheme word boundary

$(\ldots)=$ syllable boundary

The functional explanation is that these mismatches create larger units, they concatenate pieces like a zipper, with some sort of interlocking principle. Sometimes this dovetail device is the regular pattern, sometimes it comes as some sort of parasitic construction.

\subsection{Intermediate Summary}

The picture that emerges is that in the relevant constructions (see (1) - (17) below), verb movement is blocked because it creates a structure that violates phonological wellformedness constraints. The parser of phonological constituents cannot assign a legitimate structure to the syntactic object when a proclitic-like element ends up in a right peripheral position. As soon as some phonological material follows the phonological parser finds a host and the structure is saved. 


\section{Parsing problems with speech act adverbials in the pre-field}

In this section I would like to present another restriction on V2. The observation can be laid down as follows. Some expressions, which semantically act as speech act adverbials or some sort of adverbials commenting on the mode of uttering (see the examples below), can occupy a position before the regular 'Vorfeld'.

(75) Ehrlich gesagt, ich bin von dir total enttäuscht.

Honestly said, I am of you totally disappointed.

'To be honest/ honestly, I am completely disappointed with you.'

(76) Ehrlich, ich bin von dir total enttäuscht.

(77) Ganz offen gestanden, ich bin von dir total enttäuscht

(78) Ganz offen, ich bin von dir total enttäuscht.

From these examples it is not obvious that the pre-comma string is indeed an integral part of the sentence and should therefore be integrated into the core tree of the respective clause. However, a few arguments can be given. In a theory of adverbials like Cinque (1999), these elements are taken to pattern like other adverbials and occupy a specific (base) position in the tree of sentence universally a very high position in the tree of a sentence. However, there is also strong evidence from German clause structure itself that these elements can occupy a sentence internal position. They are fine both in the 'Vorfeld' directly preceding the finite verb or in the upper 'Mittelfeld' (middle field)s.

(79) Ehrlich gesagt bin ich von dir total enttäuscht.

8 To argue for a clause internal reading one has to make sure that the intonation is different from a paranthetical structure, which is also possible with this word order. (80), however is also fine without intonational setting off, i.e. (80) can be read / pronounced without pauses integrating 'ehrlich gesagt' like any other adverbial forming an intonational phrase with following clause internal material. 
(80) Ich bin ehrlich gesagt von dir total enttäuscht.

This is a strong enough piece of evidence for the integration of this sort of adverbials into the sentence (CP) they modify. (81) - (86) bring some more frequently used examples.

(81) Ganz nebenbei bemerkt, ich habe mir die Sache ganz anders vorgestellt. Wholly nearby remarked, I have the story completely differently pictured

(82) Ganz nebenbei, ich habe mir die Sache ganz anders vorgestellt.

(83) Ganz nebenbei bemerkt habe ich mir die Sache ganz anders vorgestellt. 'By the way, I've had a completely different idea about it.'

(84) Im Vertrauen gesagt, ich hab die Schnauze voll. In confidence said I have the moth full.

(85) Im Vertrauen, ich hab die Schnauze voll.

(86) Im Vertrauen gesagt habe ich die Schnauze voll. 'Confidentially, I've got enough!'

(87) gives a list of pretty frequent adverbials that pattern exactly alike (some examples are inspired from Pittner (1999).

(87) offen gestanden offen gesagt (ganz) im Vertrauen gesagt hinter vorgehaltener Hand gesagt zugegeben ernst(haft)gesagt ohne Scheiß gesagt nebenbei bemerkt / gesagt frankly

confidentially ??? confidentially admittedly seriously speaking no kidding as a marginal remark, by the way 
am Rande bemerkt

kurz gesagt

ohne zu übertreiben

ohne Übertreibung gesagt

überspitzt formuliert

ohne Umschweife gesagt

mit anderen Worten gesagt / gesprochen

anders ausgedrückt / gesagt

wenn ich ehrlich bin / sein soll

mit Verlaub gesagt / zu sagen as a marginal remark, by the way

briefly, in brief

without exaggerating

without exaggerating

with (a bit of) exaggeration

to say it straight to the point

to put it differently

to put it differently

honestly

with all due respect

All these expressions come in a certain pattern, there is something - mostly some adverbial like phrase and then a verbal form, mostly a participle of a verbum dicendi, i.e. of a verb of communication, a verb of saying (always underlined in the examples.) However, as illustrated above, it is also possible to drop the performative verb (76), (78), (82), (85). One can obtain the same effect if one leaves out the verbal part (short form ${ }^{9}$ ). Semantically the sentences either with the verbal element or with just the short form are equal. Now comes the observation. (75) - (78) are V3 structures, in classical terms: the adverbials seem to be CP-adjoined. If the short form is placed within the regular pre-field giving rise to V2, the sentences are bad (88)-(90); whereas the long form is a good occupant of the 'Vorfeld', see (79), (83), (86).

(88) *Ehrlich bin ich total enttäuscht von dir.

(89) *Nebenbei habe ich mir die Sache anders vorgestellt.

(90) *Im Vertrauen hab ich die Schnauze voll.

9 Often the short form sounds better if the adverbial element 'ganz' (completely, wholly) precedes it. This is, however, just an improvement, it is not obligatory. 
The question is: why is V2 blocked in these cases? It cannot be that the XPs in Spec,CP are no legitime occupants of the 'Vorfeld'. Under other conditions strings like 'im Vertrauen' or 'ehrlich' are fine in sentence initial position. The following data seem to suggest an explanation for the pattern. In some V2 cases dropping of the verbal part does not necessarily lead to ungrammaticality as in the above examples (88)-(90). Consider the following data in (91) to (96). The reading, however, is such that the speech act oriented interpretation is impossible.

(91) Am Rande bemerkt, steht da auch eine Telefonzelle (für den Fall...) 'By the way, there's a phone booth, ... just in case...'

(92) Am Rande steht da auch eine Telefonzelle.

'On the edge of it, there's also phone booth.' (local reading) /\#\#'By the way...' (speech act reading)

(93) Nebenbei bemerkt, ist so ein Job gar nicht zu schaffen.

'By the way, such a job is undoable.'

(94) Nebenbei ist so ein Job gar nicht zu schaffen.

'In addition to what you are already doing, such a job is too much.' (manner reading) /\#\#‘By the way...'

(95) Offen gestanden, war der Tresor ein Kinderspiel für den Dieb.

'Frankly (speaking), the safe was a child's play for the thief.'

(96) Offen war der Tresor ein Kinderspiel für den Dieb.

'Being open, the safe was a child's play for the thief.' /\#\#'Frankly,...'

Thus, if the adverbial form is not unambiguously specified for a speech act reading, this reading will not emerge. In case a reasonable manner reading (or 
something similar) is possible, the sentence is grammatical, but only with that reading.

Second, related observation: German has 'bare' adverbials that are inherently speech act oriented, i.e. they cannot have a reading where they can possibly modify or affect the interpretation of the proposition in any way. These obligatorily speech act referring elements are: 'übrigens', 'erstens', 'zweitens' (by the way, first(ly), second(ly) - respectively - and so on ${ }^{10}$ and marginally 'ungelogen' (literally: 'un-lied', meaning truely). Being unable to get a proposition internal reading these expressions can appear in the Vorfeld without triggering an unwanted interpretation or leading to ungrammaticality (97). Unsurprisingly they are also fine in the pre-prefield (V3) (98) or in the upper middle field (99). The semantics is always the same. They are bad, however, if they are put in a position close to the right sentence bracket (100).

(97) Übrigens bin ich vorige Woche in München gewesen.

(98) Übrigens, ich bin vorige Woche in München gewesen.

(99) Ich bin übrigens vorige Woche in München gewesen.

(100) *Ich bin vorige Woche in München übrigens gewesen.

'By the way, I was in Munich last week.'

And thirdly: more research is required concerning the following findings. Frey and Pittner (1998) mention in a footnote that scrambling of some (short, adjective-like) manner adverbials is bad (101) vs. (102).

10 But interestingly not: 'letztens' ('finally, as the last'), which has a non speech act reading, meaning 'recently', 'some time ago'. This lexical feature seems to block the use of 'letztens' as speech act adverbial. 
(101) Sie hat jedes Hemd sorgfältig gebügelt.

(102) *Sie hat sorgfältig jedes Hemd gebügelt

'She ironed every shirt carefully.'

Whatever the reason for this behavior is, the topmost position in the upper middle field seems to be forbidden for adverbials with a manner interpretation. Nevertheless one can find manner adverbials there. The interesting thing is that HERE we observe the opposite to what happens in the 'Vorfeld'. The relevant sentences are grammatical, but the reading of the adverbials must be speech act oriented. A manner reading is impossible ${ }^{11}$.

(103) Ich bin (ganz) ehrlich von dir total enttäuscht.

(104) Ich bin (ganz) nebenbei erst seit gestern von dieser Sache überzeugt.

(105) Ich habe (ganz) im Vertrauen erst gestern von dieser Sache erfahren.

Thus, a sentence corresponding in word order to (102) is not necessarily ungrammtical, consider (106) and (107).

(106) Sie hat (ganz) ehrlich alle Fragen beantwortet.

Honestly, she answered all questions.

(107) Sie hat (ganz) ernsthaft alle Aufgaben gemacht.

Really/Seriously, she did all tasks.

However, '(ganz) ehrlich' cannot get a reading where the answering is done in a honest way, i.e. without cheating; but - as the translation suggests, the only

11 This finding should be considered crucial for the discussion whether V2 is a blind role that puts the finite verb between the first constituent and the rest, or whether there is a decisive semantic and categorial difference between the 'Vorfeld' and the highest position in the middle field. 
interpretation possible is that the speaker of (106) wants to convey explicitly that the statement is taken to be true. The same for (107): 'ernsthaft' cannot mean that she worked on every task with seriousness.

The picture that emerges can be summarized in a table (108).

\begin{tabular}{|l|l|l|l|}
\hline & $\begin{array}{l}\text { 'Vor-vor- } \\
\text { Feld' (V3) }\end{array}$ & $\begin{array}{l}\text { Canonical } \\
\text { 'Vorfeld' (V2) }\end{array}$ & $\begin{array}{l}\text { Upper middle-field } \\
\text { position (TopP) }\end{array}$ \\
\hline $\begin{array}{l}\text { Complex, i.e. unambiguous } \\
\text { speech act adverbial }\end{array}$ & ok & ok & ok \\
\hline $\begin{array}{l}\text { Bare adverbial, i.e. short } \\
\text { form }\end{array}$ & ok & */ other reading & ok \\
\hline $\begin{array}{l}\text { Bare, but inherently speech } \\
\text { act related adverbial } \\
\text { (e.g. 'übrigens') }\end{array}$ & ok & ok & ok \\
\hline $\begin{array}{l}\text { Adverbial with a reading } \\
\text { that is not speech act } \\
\text { related, (mostly manner) }\end{array}$ & $*$ & ok & $*$ \\
\hline
\end{tabular}

This suggests very much that the speech act reading must be made explicit. This can be done in two ways: (i) either a long form is used, which by its very meaning must be interpreted as speech related (upper line), or (ii) by putting the adverbial in an unambiguous position (V3)(or some TopP-like position in the upper middle field) (first and third column). If the (bare) adverbial is put into the regular first position in a V2 clause, the parser wants to assign a sentence internal reading (mostly manner, but also local etc.). If such a reading is available, the sentence is grammatical, but there is no way to get a speech act reading. If no such reading can be triggered, the interpretative parser crashes. Thus, again we have a parsing related restriction for verb second. This time not from the PF path, but from the CI side. 


\section{References}

Abney, Steve (1991) Syntactic affixation and performance structures. In: Views on Phrase Structure, K. Leffel and D. Bouchard (eds.), 215-227. Dordrecht/Boston/London: Kluwer.

Alexiadou, Artemis, E. Anagnoastopoulou, S. Barbiers and H.-M. Gärtner (2002) Dimensions of Movement - Introduction. Linguistik Aktuell Linguistics Today, 3-16. Amsterdam/Philadelphia: John Benjamins.

Chomsky, Noam A. (2001) Derivation by Phase. In: A Life in Language, M. Kenstowicz and K. Hale, 1-52. Cambridge, Mass: MIT Press.

den Besten, Hans (1977/1983) On the interaction of root transformations and lexical deletive rules. Published in: On the Formal Syntax of the Westgermania, W. Abraham (ed.), 47-131. Amsterdam: John Benjamins.

Fanselow, Gisbert (2002) Münchausen-Style Head Movement and the Analysis of Verb Second. Ms. University of Potsdam.

Frey, Werner, and Karin Pittner (1998) Zur Positionierung der Adverbiale im Deutschen Mittelfeld. Linguistische Berichte 176, 489-534. Westdeutscher Verlag.

Grimshaw, Jane (1991) Extended projection. Ms., Brandeis University, Brandeis, Mass.

Hahnemann, Suzan (1999) Vergleiche im Vergleich. Tübingen: Niemeyer.

Haider, Hubert (1997) Typological Implications of a directionality constraint on projections. In: Studies on Universal Grammar and Typological Variation, Artemis Alexiadou and Tracy Hall (ed.), 17-33. Amsterdam/Philadelphia: John Benjamins.

Kajita, Masaru (1977) Towards a dynamic model of syntax. In: Studies in English Linguistics, Kajita, M., N. Toshio and M. Ukaji, 44-76. Asahi Press. 
Koopman, Hilda, and A. Szablolcsi (2000) Verbal Complexes, Cambridge MA: MIT Press.

Meinunger, André (2001) Restrictions on Verb Raising, Linguistic Inquiry [Squib] 32.4: 732-740.

Müller, Gereon (to appear) Verb-Second as vP-First In: Journal of Comparative Germanic Linguistics.

Pittner, Karin (1999) Adverbiale im Deutschen. Untersuchungen zu ihrer Stellung und Interpretation. (Studien zur deutschen Grammatik 60). Stauffenberg. Tübingen.

Rapp, Irene, and Arnim v. Stechow (1999) Fast-Hand-out, presented at ZAS/Berlin.

Riemsdjik, Henk van (1998) Trees and Scions - Science and Trees: Fest-WebPage for Noam Chomsky (32pp) URL:

http://mitpress.mit.edu/chomskydisc/riemsdyk.html. - apparently not available anymore.

Riemsdjik, Henk van (2000) A far from simple matter: Syntactic reflexes of syntax-pragmatics misalignments. In: Semantics, Pragmatics and Discourse. Perspectives and Connections. A Festschrift for Ferenc Kiefer, R. M. Harnish and I. Kenesei (eds.). Amsterdam: John Benjamins.

Rizzi, Luigi (1997) The fine structure of the left periphery. In: Elements of Grammar: handbook in generative syntax. L. Haegemann (ed.) Dordrecht: Kluwer, 281-337.

Wilder, Chris (1998) Transparent free relatives ZAS Papers in Linguistics 10: 191-199. Berlin ZAS.

Zimmermann, Ilse (1991) Die subordinierende Konjunktion wie. In: Fragesätze und Fragen, Marga Reis and Inger Rosengren (eds.), 113-122. Tübingen: Niemeyer. 